\title{
PENERAPAN METODE PEMBELAJARAN TEAM TEACHING DALAM UPAYA MENINGKATKAN HASIL BELAJAR MATA KULIAH MATEMATIKA EKONOMI DI UNINDRA
}

\author{
Elin Karlina ${ }^{1}$, Fadli Rasam ${ }^{2}$ \\ Universitas Indraprasta PGRI, Indonesia ${ }^{12}$ \\ Elinkarlina27@yahoo.com¹, fadrasam@gmail.com²
}

Received: 22 Maret 2020

Revised: 24 Maret 2020

Accepted: 28 Maret 2020

\begin{abstract}
Penelitian ini bertujuan untuk mengetahui penerapan metode pembelajaran team teaching dalam upaya meningkatkan hasil belajar mata kuliah matematika ekonomi Mahasiswa Program Studi Pendidikan Ekonomi Universitas Indraprasta PGRI. Metode yang akan digunakan adalah dengan eksperimen. Penelitian dilakukan pada mahasiswa semester satu, dimana mereka masih peralihan masa dari tingkat SMA/SMK/MA/sederajat ke jenjang perguruan tinggi. Penelitian ini menggunakan dua kelas untuk penelitian sebanyak 77 mahasiswa, kelas A sebagai kelas kontrol dengan metode ceramah dan kelas B sebagai kelas eksperimen dengan metode team teaching, dari kedua metode yang digunakan, peneliti akan melihat dan membandingkan hasil belajar mahasiswa/i. Berdasarkan penelitian dan perhitungan SPSS diperoleh hasil penelitian sebagai berikut: (1) kedua data normal dan homogen, (2) terdapat perbedaan antara mahasiswa/i yang pembelajaraanya menggunakan metode team teaching dengan metode ceramah. Hasil penelitian menunjukan bahwa, mahasiswa/i yang kegiatan pembelajarannya menggunakan metode team teaching dapat meningkatkan hasil belajar pada mata kuliah matematika ekonomi.
\end{abstract}

Keywords: Team Teaching, Hasil Belajar, Matematika Ekonomi

(*) Corresponding Author: $\quad$ Elin Karlina, Elinkarlina27@yahoo.com, 085697712191

How to Cite: Karlina, Elin \& Rasam, Fadli. (2020). Penerapan Metode Pembelajaran Team Teaching Dalam Upaya Meningkatkan Hasil Belajar Mata Kuliah Matematika Ekonomi Di UNINDRA. Research and Development Journal of Education, 6(2), 65-73.

\section{INTRODUCTION}

Mata Kuliah Matematika Ekonomi merupakan mata kuliah yang berhubungan dengan aplikasi matematika dalam ilmu ekonomi yang berupa fungsi permintaan, fungsi penawaran, keseimbangan pasar, pajak, dan subsidi, BEP, deret, serta diferensial. Proses pembelajaran mata kuliah matematika ekonomi pada perguruan tinggi terkesan sulit, sedangkan mahasiswa yang belajar mata kuliah matematika ekonomi pada perguruan tinggi sebagian besar berasal dari multi disiplin ilmu pada tingkat SMA/SMK/MA/sederajat, ditambah mata kuliah ini ada pada semester satu, dimana mahasiswa/i masih dalam tahap masa peralihan dari sekolah menengah atas ke tingkat perguruan tinggi yang semuanya sangat berbeda, baik cara mereka belajar maupun metode pembelajaran yang digunakan.

Keberhasilan dunia pendidikan tidak terlepas dari penggunaan metode pembelajaran. Metode pembelajaran merupakan suatu cara yang dipakai oleh pendidik agar kegiatan pembelajaran dapat tercapai dengan maksimal, sehingga peserta didik dapat belajar secara baik, sehingga pembelajaran berlangsung secara efektif dan efisien. Arti penting suatu metode pembelajaran sangat tergantung dari penerapan kratifitas pendidik 
dalam mengajar dan hal ini ssangat dibutuhkan dalam sekolah maupun perguruan tinggi, khususnya bagi pembelajaran di dalam kelas.

Trianto (2010), menyebutkan bahwa model pembelajaran adalah suatu perencanaan atau pola yang digunakan sebagai pedoman dalam merencanakan pembelajaran di kelas atau pembelajaran tutorial. Pupuh dan Sobry S (2010) berpendapat makin tepat metode yang digunakan oleh guru dalam mengajar, diharapkan makin efektif pula pencapaian tujuan pembelajaran. Selain itu pula, jika metode pembelajaran yang digunakan tepat, maka akan meningkatkan hasil belajar peserta didik.

Hasil belajar dapat diketahui selama kegiatan atau proses pembelajaran berlangsung, yaitu bisa dilihat pada saat dosen mengajar apakah mahasiswa tersebut dapat memahami apa yang sudah disampaikan dan diinginkan oleh dosen, serta sesuai dengan apa yang telah ditetapkan dalam kurikulum. Hasil belajar yang dicapai mahasiswa/i sangat beragam, ada yang tinggi, sedang, dan rendah. Pembelajaran dikatakan berhasil jika perserta didik mampu menguasi kompetensi yang diharapkan dalam suatu materi ajar, serta peserta didik terlibat secara aktif, baik fisik, mental maupun sosial dalam proses pembelajaran, yaitu dengan menunjukkan kegairahan belajar yang tinggi, semangat belajar yang besar, dan rasa percaya diri sendiri. Adapun salah satu faktor yang menyebabkan mahasiswa/i kurang aktif saat pembelajaran, terutama pada mata kuliah yang bersifat hitungan (matematika) adalah pemilihan metode dalam pembelajaran. Apabila metode pembelajaran yang digunakan oleh pengajar bersifat monoton, maka akan membuat mahasiswa/i merasa bosan bahkan kurang tertarik dengan materi yang diajarkan, sehingga hal ini dapat menyebabkan mahasiswa/i tidak menunjukkan rasa antusias terhadap materi yang dijelaskan dan mereka dapat menganggap bahwa pembelajarannya terkesan sulit untuk dipahami.

Pembelajaran yang umum digunakan oleh dosen biasanya dengan metode tanya jawab, tugas, dan latihan, akan tetapi metode tersebut belum sepenuhnya berjalan secara efektif, hanya sedikit mahasiswa/i yang antusias dalam belajar dan mau bertanya mengenai materi pembelajaran yang belum dipahami. Hal tersebut menunjukkan bahwa keaktifan mahasiswa/i dalam proses pembelajaran perlu ditingkatkan agar hasil belajar pun dapat meningkat. Oleh sebab itu, guru atau dosen harus memahami ragam gaya belajar (learning style) peserta didik satu dengan yang lainnya, bahkan harus memahami tingkat perkembangan yang sedang dialami mereka.

Pada kesempatan ini peneliti mencoba untuk memberikan sebuah solusi kreatif dalam rangka memaksimalkan segenap potensi yang ada. Solusi ini juga sekaligus untuk memberikan dan mengembangan kemajuan yang berkelanjutan terhadap kemampuan dosen. Dalam hal ini, peneliti mencoba untuk memberikan sebuah solusi yaitu dengan menerapkan metode team teaching dalam kegiatan pembelajaran sebagai suatu inovasi dan kratifitas dalam upaya meningkatkan hasil belajar mahasiswa. Menurut Sukardi (2013), Metode mengajar beregu (team teaching) adalah suatu metode mengajar dimana pendidiknya lebih dari satu orang yang masing-masing mempunyai tugas. Menurut peneliti sendiri metode team teaching dapat menjadi sebuah inovasi dalam pembelajaran dan metode tersebut dapat memberikan solusi terhadap berbagai kendala yang dihadapi oleh dosen dalam melaksanakan proses mengajar di kelas. Penggunaan metode mengajar beregu (team teaching) dalam mata kuliah matematika ekonomi oleh dosen di kelas, menurut peneliti akan sangat membantu dalam memperjelas materi yang disampaikan. Misalnya seorang dosen menjelaskan materi perkuliahan di depan kelas, dosen yang lain berdiri di belakang kelas memperhatikan mahasiswa dari belakang apabila ada yang sibuk sendiri dosen tersebut yang menegur sehingga dosen satunya tetap bisa melanjutkan penjelaskan materi.

Bertitik tolak dari uraian di atas, adapun rumusan masalah dalam penelitian ini adalah Apakah dengan Penerapan Metode Pembelajaran Team Teaching dapat 
Meningkatkan Hasil Belajar Mata Kuliah Matematika Ekonomi di Universitas Indraprasta PGRI ?

\section{KAJIAN PUSTAKA}

\section{Pengertian Hasil Belajar}

Menurut Dimyati dan Mudjiono, hasil belajar adalah hasil dari suatu komunikasi dalam proses belajar dan pembelajaran dan pada kegiatan akhir, guru menilai hasil belajar siswa berdasarkan hasil kerja siswa yang akan digunakan untuk menilai kemampuan siswa (Dimyanti dan Mudjiono, 2013). Sedangkan menurut Hamalik, mendefinisikan hasil belajar sebagai tingkat penguasaan yang dicapai oleh pelajardalam mengikuti proses belajar mengajar sesuai dengan tujuan pendidikan yang ditetapkan (Hamalik, 2014).

Hasil belajar merupakan pola-pola perbuatan, nilai-nilai, pengertian-pengertian, sikap-sikap, apresiasi, dan keterampilan. Hasil belajar tampak sebagai terjadinya perubahan tingkah laku pada diri siswa, yang dapat diamati dan diukur dalam bentuk perubahan pengetahuan (kognitif), sikap (afektif) dan keterampilan (psikomotorik) (Fajri Ismail, 2014).

Menururt Bloom dalam Suprijono (2015), hasil belajar mencakup kemampuan kognitif, afektif, dan psikomotorik, (1) domain kognitif meliputi knowledge (pengetahuan, ingatan), comprehension (pemahaman, menjelaskan, meringkas, contoh), application (menerapkan), analysis (menguraikan, menentukan hubungan), synthesis (mengorganisasikan, merencanakan, membentuk bangunan baru), dan evaluation (menilai), (2) domain afektif meliputi receiving (sikap menerima), responding (memberikan respons), valuing (nilai), organization (organisasi), characterization (karakteristik), (3) domain psikomotor meliputi initiatory, pre-routine, rountinized. Psikomotor juga mencakup keterampilan manipulasi yang melibatkan otot dan kekuatan fisik, karena keterampilan itu sendiri dapat menunjukkan tingkat keahlian seseorang dalam menyelesaikan suatu tugas tertentu.

Berdasarkan uraian yang telah dikemukakan di atas dapat disimpulkan bahwa hasil belajar adalah hasil dari perubahan, perkembangan dan peningkatan dari mahasiswa sendiri dalam proses pendidikan kearah yang lebih baik setelah ia menerima pengalaman belajar dan dapat dinyatakan dengan angka, huruf atau kata-kata.

\section{Pengertian Metode Team Teaching}

Engkaswara (2003), menyatakan team teaching adalah suatu sistem mengajar yang dilakukan oleh dua orang guru atau lebih, mengajar sejumlah anak yang mempunyai perbedaan-perbedaan baik minat, kemampuan maupun tingkat kelasnya. Definisi tersebut sama seperti apa yang dijelaskan oleh Sudjana (2004), team teaching pada dasarnya adalah metode pembelajaran yang dilakukan oleh dua orang guru atau lebih yang saling bekerjasama mengajar kelompok siswa.

Menurut Ahmadi dan Prasetya (dalam Jamal Ma'mur, 2010), team teaching adalah pengajaran yang dilaksanakan secara bersama oleh beberapa guru. Guru yang menyajikan bahan pelajaran dengan metode mengajar beregu ini menyampaikan bahan pelajaran dalam waktu dan tujuan yang sama. Salah seorang pendidik biasanya ditunjuk sebagai koordinator. Cara pengujiannya, pendidik membuat soal masing-masing, kemudian soal tersebut digabung. Jika ujian lisan maka setiap siswa yang diuji harus langsung berhadapan dengan team pendidik tersebut (Sukardi, 2013)

Metode pengajaran Team Teaching merupakan metode yang melibatkan beberapa unsur dalam pelaksanaan proses mengajar. Unsur-unsur tersebut bisa menggunakan kuantitas guru atau pendidik yang jumlahnya lebih dari satu untuk menangani satu mata 
pelajaran atau memiliki pembagian tanggung jawab di dalam proses mengajar. Tim tidak hanya terdiri atas guru formal saja, tetapi juga atas guru nonformal dan orang-orang luar yang dianggap perlu sesuai dengan keahlian dan tujuan pembelajaran yang dibutuhkan (Nasih dan Kholidah, 2013).

\section{Langkah-Langkah Pengajaran Beregu}

a. Pendahuluan

Dosen dalam hal ini pimpinan tim harus menjelaskan tentang kopetensi yang harus dikuasai oleh mahasiswa setelah mengikuti proses pembelajaran. Selanjutnya memberikan penjelasan, bahwa pelajaran pada jam ini akan disajikan oleh beberapa orang dan apabila perlu anggota tim diperkenalkan kepada mahasiswa (Ramayulis, 2005).

b. Penyajian

Anggota-anggota tim memberikan informasi penjelasan kepada mahasiswa tentang bahan pelajaran. Pada waktu seorang dosen sedang menjelaskan materi, anggota lain diperkenankan memberikan keterangan, baik berupa tambahan atau pengurangan materi. Setelah anggota yang menyelangi itu selesai memberikan keterangan tambahannya, atau pengurangan keterangan, maka anggota pertama tadi meneruskan keterangannya. Apabila ada ketidaksesuaian antara keterangan anggota pertama dengan anggota yang lainnya, maka mungkin terjadi diskusi atau musyawarah antara anggota tim. Anggota kedua melanjutkan pelajaran. Proses penyajian bahan pada langkah ketiga ini berlangsung seperti pada langkah kedua. Anggota ketiga melanjutkan pelajaran. Prosesnya sama dengan yang di atas. Pemimpin tim menyajikan kesimpulan tentang isi bahan pelajaran.

c. Penutup

Mahasiswa boleh menyalin atau bertanya atau memberikan tanggapan-tanggapan terhadap isi pelajaran. Penutup ini juga bisa disikan dengan penilaian.

Dari penjelasan diatas maka peneliti dapat mengambil sebuah kesimpulan bahwa metode adalah cara seorang dosen dalam menyampaikan materi yang diajarkan dalam menyukseskan proses pembelajaran, metode mengajar beregu atau team teaching menurut peneliti sendiri adalah cara guru dalam mengajar dimana dalam pelaksanannya dilakukan secara tim oleh dua orang dosen atau lebih.

\section{METHODS}

Sampel penelitian ini sebanyak 77 mahasiswa/i semester satu yang ditentukan dengan menggunakan teknik purposive sampling. Sampel yang diperoleh dari populasi di mana kelas eksperimen menggunkan metode Team Teaching (Mengajar Beregu) dan kelas kontrol menggunakan model pembelajaran konvensional.

Metode penelitian yang digunakan adalah eksperimen semu (quasi experiment), karena dalam penelitian ini peneliti tidak mengontrol semua variabel yang relevan (Saputra \& Prasetyono, 2020). Penelitian eksperimen ini dilakukan di dua kelas, yaitu kelas kontrol dan kelas eksperimen. Pada kelas eksperimen menggunakan metode pembelajaran Team Teaching (Mengajar Beregu), sedangkan kelas kontrol menggunakan pembelajaran konvensional. Rancangan penelitian ini adalah Posttes-Only Control Design yang berbentuk quasi eksperimen (Sugiyono, 2009) adalah sebagai berikut: 
Tabel 1

Posttest-Only Control Group Design

\begin{tabular}{ccc}
\hline Kelompok & Perlakuan & Posttest \\
\hline Eksperimen & $\mathrm{X}$ & $\mathrm{O}$ \\
Kontrol & - & $\mathrm{O}$ \\
\hline
\end{tabular}

Sumber: Peneliti 2020

Hasil dari perlakuan yang diberikan dapat dilihat dari perbedaan antara hasil posttest dari kelas eksperimen yang menggunakan metode pembelajaran team teching dan kelompok kontrol yang menggunakan metode pembelajarana konvensional. Teknik pengumpulan data yang dilakukan yaitu berupa tes yang diberikan kepada mahasiswa/i dalam bentuk tes essay. Tes tersebut dilakukan dengan tujuan untuk melihat kemampuan mahasiswa untuk menggunakan pengetahuan yang telah mereka bangun dalam menyelesaikan permasalahan matematika ekonomi.

Dalam penelitian ini analisis data dilakukan dengan statistik deskriptif dan inferensial. Statistik deskriptif dilakukan agar memperoleh deskripsi mengenai karakteristik penyebaran skor setiap variabel yang diteliti berupa hitungan rata-rata, simpangan baku, distribusi frekuensi, varians, modus, dan median serta pembuatan histogram. Sedangkan statistik inferensial dilakukan dengan uji T-formula (t-hitung) pada t-test. Teknik uji beda rerata dalam penelitian ini menggunakan uji t tidak berpasangan. Semua pengukuran dilakukan pada taraf signifikansi $\alpha$ 0.05. Adapun langkah-langkah yang diambil dalam analisis data, yaitu:

1. Mengolah skor dari instrumen penelitian dan penyebaran data disajikan dalam bentuk pengelompokkan data, mean, median, modus, simpangan baku, distribusi frekuensi, varians, dan pembuatan histogram dari skor setiap variabel.

2. Uji persyaratan analisis yang terdiri dari uji normalitas dan uji homogenitas. Pengujian normalitas sampel dilakukan dengan uji liliefors, dan pengujian homogenitas dengan uji F (Fisher).

\section{RESULTS \& DISCUSSION}

\section{Hasil Penelitian}

Untuk memperoleh gambaran mengenai karakteristik distribusi skor dari masingmasing variabel yang diteliti, disajikan nilai rata-rata, varians, simpangan baku, distribusi frekuensi, mean, modus, serta histogram. Data nilai rata-rata, varians, simpangan baku, distribusi frekuensi, mean, dan modus disajikan dalam tabel berikut ini:

Tabel 2.

Deskripsi Data Hasil Belajar Matematika Ekonomi

\begin{tabular}{lcc}
\hline & $\begin{array}{c}\text { Hasil Belajar } \\
\text { Kelas Eksperimen }\end{array}$ & Kelas Kontrol \\
\hline Maean & 64,5238 & 56,0811 \\
Median & 65,0000 & 50,0000 \\
Mode & 75,00 & 45,00 \\
Standar Deviasi & 18,03822 & 16,58878 \\
Variansi & 325,377 & 275,188 \\
Minimal & 30,00 & 25,00 \\
Maksimal & 95,00 & 95,00 \\
\hline
\end{tabular}

Sumber: Peneliti 2020 
Teknik analisis data menggunakan teknik analisis T-formula (t-hitung) pada t-test uji beda rerata dengan uji t tidak berpasangan. Namun, terlebih dahulu melakukan pengujian persyaratan analisis yaitu dengan uji normalitas dan homogenitas.

\section{Uji Normalitas}

Pengujian normalitas dilakukan pada data variabel hasil belajar kelas eksperimen dan kelas kontrol dengan menggunakan uji liliefors pada $\alpha=0.05$. Hasil pengujian normalitas terangkum pada tabel berikut:

Tabel 3.

Pengujian Normalitas

\begin{tabular}{|c|c|c|c|}
\hline & & \multicolumn{2}{|c|}{ Kelas_Kontrol Kelas_Eksperimen } \\
\hline $\mathrm{N}$ & & 37 & 42 \\
\hline \multirow{3}{*}{ Normal Parameters ${ }^{\mathrm{a}, \mathrm{b}}$} & Mean & 56,0811 & 64,5238 \\
\hline & Std. & 16,5887 & \multirow{2}{*}{18,03822} \\
\hline & tion & 8 & \\
\hline \multirow{3}{*}{$\begin{array}{l}\text { Most } \\
\text { Differences }\end{array}$} & Absolute &, 184 &, 148 \\
\hline & Positive & , 184 & 080 \\
\hline & Negative &,- 117 &,- 148 \\
\hline Kolmogorov-Smirnov & & 1,117 & ,958 \\
\hline Asymp. Sig. (2-tailed) & &, 165 &, 317 \\
\hline
\end{tabular}

Pada tabel 3 pengujian normalitas menggunakan uji Kolmogorrov smirnov dengan keterangan adalah sama dengan uji liliefors. Didapat untuk variabel hasil belajar kelas eksperimen $(0,317>0,05$ dan kelas kontrol $(0,165>0,05)$, karena tingkat signifikansi atau nilai probabilitas di atas 0,05 maka dikatakan distribusi kedua sampel adalah normal.

\section{Uji Homogenitas}

Pengujian homogenitas dilakukan pada data variabel hasil belajar kelas eksperimen dan kelas kontrol dengan menggunakan uji $\mathrm{F}$ (Fisher) pada $\alpha=0.05$. Hasil pengujian homogenitas terangkum pada tabel berikut:

Tabel 4.

Uji Homogenitas

\begin{tabular}{cccc}
\hline Levene Statistic & df1 & df2 & Sig. \\
\hline, 580 & 1 & 77 &, 449 \\
\hline Sumber: Peneliti 2020 & & &
\end{tabular}

Pada tabel 4 pengujian homogenitas menggunakan uji Fisher. Didapat untuk variabel hasil belajar matematika ekonomi baik kelas eksperimen dan kontrol $(0,449$ > $0,05)$, karena tingkat signifikansi atau nilai probabilitas di atas 0,05 maka dikatakan distribusi kedua sampel adalah homogen.

Penelitian ini bertujuan ingin memperoleh jawaban secara empirik Penerapan Metode Pembelajaran Team Teaching dalam upaya Meningkatkan Hasil Belajar Mata Kuliah Matematika Ekonomi di Universitas Indraprasta PGRI. Adapun hubungan tersebut dapat dijelaskan dengan menggunakan analisis uji beda rerata dengan uji $t$ tidak berpasangan dengan menggunakan program SPSS. 
Tabel 5.

Ringkasan Hasil Penelitian

\begin{tabular}{ccc}
\hline & Sig (2-tailed) & t hitung \\
\hline Hasil Belajar Matematika Ekonomi & 0,034 & 2,155 \\
\hline Sumber: Peneliti 2020
\end{tabular}

Sumber: Peneliti 2020

Berdasarkan tabel 5 diketahui nilai sig $0,034<0,05$ atau thitung $(2,155)>t$ tabel (1,9963), maka dapat disimpulkan bahwa penerapan metode team teaching dapat meningkatkan hasil belajar matematika ekonomi mahasiswa/i.

\section{Pembahasan}

Hasil analisis menunjukkan bahwa pembelajaran mahasiswa/i yang menggunakan metode team teaching dapat meningkatkan hasil belajar matematika ekonomi. Sejalan dengan penelitian yang dilakukan oleh Yunita (2016) Berdasarkan hasil penelitian ini bahwa hasil belajar siswa mata pelajaran SKI sebelum menerapkan Metode Mengajar Beregu (Team Teaching) yang tergolong tinggi (baik) sebanyak 6 orang siswa (21,43\%), tergolong sedang sebanyak 16 orang siswa $(57,14 \%)$ dan yang tergolong rendah 6 orang siswa $(21,43 \%)$ dan hasil belajar mata pelajaran SKI setelah menerapkan Metode Mengajar Beregu (Team Teaching) yang tergolong tinggi (baik) sebanyak 8 orang siswa $(28,57 \%)$, tergolong sedang sebanyak 13 orang siswa $(46,43 \%)$ dan yang tergolong rendah 7 orang siswa $(25 \%)$. Hipotesis nihil yang diajukan ditolak karena besarnya " $\mathrm{t}$ " yang peneliti peroleh dalam perhitungan (to $=8,768$ ) dan besarnya " $t$ " yang tercantum pada Tabel Nilai t (tt.ts.5\% = 2,05 dan tt.ts. $1 \%=2,77$ ) maka dapat kita ketahui bahwa to adalah lebih besar daripada tt; yaitu: 2,05 $<8,768>2,77$ berdasarkan uji coba tersebut secara meyakinkan dapat dikatakan metode beregu (team teaching) yang baru itu, telah menunjukkan efektifitasnya yang nyata; dalam arti kata: dapat diandalkan sebagai metode yang baik untuk mengajarkan bidang studi sejarah kebudayaan islam pada tingkat madrasah ibtidaiyah.

Sejalan dengan Ratna Dewi (2018) Hasil penelitian menunjukkan bahwa: (1) Ada delapan model pembelajaran yang diterapkan oleh guru, dan yang representatif adalah model pembelajaran kooperatif (model 2) dibandingkan dengan model pendekatan CTL (model 6) serta model lainnya. Model pembelajaran yang diterima oleh siswa SMA dalam proses belajar mengajar adalah model pembelajaran matematika realistik (model 7) dibandingkan dengan model pembelajaran peningkatan kemampuan berpikir (model 4) serta model lainnya. (2) Ada lima metode pembelajaran yang diterapkan oleh guru SMA dan yang representatif adalah metode demonstrasi (metode 2) dibandingkan dengan metode simulasi (metode 5) serta metode lainnya. Metode pembelajaran yang representatif diterapkan guru SMA dan diterima oleh siswa adalah metode diskusi panel dan debat (metode 3) dibandingkan dengan metode bermain peran (metode 4) serta metode lainnya. (3) Hasil metode pembelajaran modern dan konvensional yang diterapkan oleh guru SMA dan diterima oleh siswa sudah bisa dikatakan efisien, efektif dan berkualitas dalam penerapannya mulai tahun 2013 - 2017. Ini berarti guru dalam menerapkan metode pembelajaran modern dan konvensional selalu memperhatikan aspek efisiensi waktu pembelajaran, dengan menyesuaikan aspek efektivitas pemanfaatan media pembelajaran untuk memperoleh hasil belajar yang berkualitas, demikian pula dengan siswa menerima metode pembelajaran modern dan konvensional ssesuai dengan efisiensi waktu pembelajaran, efektif dalam menggunakan media pembelajaran dan menunjukkan hasil evaluasi pembelajaran yang berkualitas.

Sejalan dengan Kalsum Nasution (2017) Berdasarkan hasil penelitian tersebut maka dapat dibuktikan bahwa metode pembelajaran dan hasil belajar siswa berada dikategori medium, serta terhadap hubungan yang kuat antara metode pembelajaran 
terhadap hasil belajar siswa, dengan demikian maka dapat dikatakan bahwa hasil belajar siswa dapat ditingkatkan dengan adanya penggunaan metode pembelajaran yang tepat dan baik oleh guru dalam proses pembelajaran di sekolah.

Berdasarkan hasil penelitian penerapan metode pembelajaran team teaching mampu meningkatkan hasil belajar mata kuliah matematika ekonomi. Metode pembelajaran mempermudah proses kegiatan belajar-mengajar. Keberhasilan suatu proses pembelajaran dapat diukur melalui seberapa banyak cara yang digunakan didalam mengajar (Sugiyono, 2006). Dalam proses pembelajaran, dosen dapat menggunakan berbagai metode pembelajaran yang tepat dan sesuai dengan kebutuhan mahasiswa/i, dosen dapat menggunakan metode ceramah (Preaching Method), metode percobaan (Experimental method), metode latihan keterampilan (Drill method), metode diskusi (Discussion method), metode pemecahan masalah (Problem solving method), metode perancangan (projeck method), metode pembelajaran tersebut memiliki pengaruh yang kuat dan sedang terhadap peningkatan hasil belajar mahasiswa/i, setiap metode pembelajaran memiliki peranan dan keunggulan masing-masing, untuk itu diperlukan kemampuan dosen dalam menyesuaikan metode pembelajaran dalam proses pembelajaran.

\section{CONCLUSION}

Berdasarkan hasil penelitian, dapat ditarik simpulan bahwa mahasiswa/i yang kegiatan pembelajarannya menggunakan metode team teaching dapat meningkatkan hasil belajar mata kuliah matematika ekonomi atau dengan kata lain upaya meningkatkan hasil belajar mata kuliah matematika ekonomi dengan penerapan metode team teaching dikatakan berhasil.

\section{REFERENCES}

Dimyati dan Mudjiono. (2014). Belajar dan Pembelajaran, Jakarta: Rineka Cipta. Engkoswara. (2003). Dasar-Dasar Metodologi Pengajaran. Jakarta: Bina Aksara. Ismail, Fajri. (2014). Evaluasi Pendidikan. Palembang: Tunas Gemilang Press.

Jamal Ma'mur Asmani. (2010). Pengenalan Dan Pelaksanaan Lengkap Micro Teaching \&Team Teaching. Yogyakarta : Diva Press.

Hamalik, Oemar. (2014). Proses Belajar Mengajar. Jakarta : Bumi Aksara

Nasih, Ahmad Munjin dan Lilik Nur Kholidah. (2013). Metode dan Teknik Pembelajaran Pendidikan Agama Islam, Bandung: Refika Aditama.

Ramayulis. (2005). Metodologi Penddikan Agama Islam. Jakarta: Kalam Mulia.

Saputra, S., \& Prasetyono, H. (2020). The Effect Of Science Approach To The Activity Of Learning Students In Smpn 25 Tangerang City. Jurnal PAJAR (Pendidikan dan Pengajaran), 4(1), 20-30. DOI : http://dx.doi.org/10.33578/pjr.v4i1.7910

Sudjana, N. (2004). Dasar-dasar Proses Belajar Mengajar. Bandung: Sinar Baru Algensindo.

Sugiyono. (2009). Metode Penelitian Pendidikan. Bandung: Alfabeta

Sukardi, Ismail. (2013). Model-Model Pembelajaran Modern; Bekal Untuk Guru Profesional. Palembang: Tunas Gemilang press.

Suprijono, A. (2015). Cooperative Learning Teori dan Aplikasi PAIKEM Edisi Revisi. Yogyakarta: Pustaka Pelajar.

Trianto. (2010). Mendesain Model Pembelajaran Inovatif- Progesif. Jakarta: Kencana. 
Pupuh Faturrohman \& Sobry M. S. (2010). Strategi Belajar Mengajar melalui Penanaman Konsep Umum \& Konsep Islami, Bandung: Refika Aditama

Yunita, Inti. (2016). Penerapan Metode Mengajar Beregu (Team Teaching) dalam Meningkatkan Hasil Belajar Siswa Kelas IV pada Mata Pelajaran SKI di MI Muhammadiyah Ulak Lebar Kecamatan Ulu Ogan Kabupaten OKU. Jurnal Ilmiah PGMI Volume 2, Nomor 1, Januari 2016. 